\title{
Debating the Burqa in France: the Antipolitics of Islamic Revival
}

\section{Z. Fareen Parvez}

Published online: 31 March 2011

(C) The Author(s) 2011. This article is published with open access at Springerlink.com

\begin{abstract}
In 2009 a French national commission was created to issue recommendations against "the burqa" and raise the possibility of a ban on the practice in certain public settings. This paper explores the different normative stakes of politicizing the burqa and the form of Islamic Revival with which it is associated. Recent scholarship has sought to overturn orientalist depictions of Islamic movements but has insisted that bodily ethical practices, such as Muslim women's veiling, constitute forms of politics. Based on ethnographic research in a women's mosque community in a poor suburb of Lyon, France, I argue that these women are not engaged in a form of politics but rather, antipolitics, a movement originally conceptualized in the 1970s and $80 \mathrm{~s}$ as a rejection of politics and a valorization of private life. Three components define their antipolitics: a reconfiguration of the private sphere against an intrusive state, a retreat into a moral community, and emphasis on spiritual conditions and achievement of serenity. In interrogating different meanings of politics and antipolitics, this paper suggests a rethinking of the relationship between "political Islam" and piety movements.
\end{abstract}

Keywords Islam $\cdot$ France $\cdot$ Gender $\cdot$ Politics

Few expressions of faith today cause as much fear and loathing in plural democracies as the "burqa." The pity and disdain many feel for these women is a nearly automatic reaction

\footnotetext{
${ }^{1}$ The term "burqa" is not employed by those in the Muslim community who are familiar with women's veiling practices. The word is currently used in France to refer to both the full body covering including the face, except the eyes, as well as a mesh-fabric covering over the eyes. These are the specific practices being debated in the French Assembly and that among adherents, are known as a "niqab" or "sitar" (which covers the eyes). The sitar is an exceptionally rare practice in France. Most of the women among whom I conducted fieldwork wore "the djelbab," which refers to a long hair and body covering that leaves the face exposed. Some of them also wore the niqab. In this paper, I switch back and forth between the terms djelbab and burqa. Most of the discourses and phenomena I describe refer to these groups of women more generally, regardless of which ones wear only a djelbab and which choose to also wear a niqab. There was little distinction made in the Assembly hearings between these practices.
}

\section{Z. F. Parvez $(\bowtie)$}

Department of Sociology, University of California, 410 Barrows Hall, Berkeley, CA 94720-1980, USA

e-mail: fareen@berkeley.edu

Present Address:

Z. F. Parvez

University of Massachusetts, Amherst, MA 01003, USA

e-mail: parvez@soc.umass.edu 
that occurs regardless of the individuals who actually wear the burqa and believe in its purpose. The burqa has come to represent a number of evils currently associated with Islam, including the oppression of women, terrorism, and radical separatism. It has become a particularly vexed issue in several secular countries from Tunisia to the Netherlands. In France it became the subject of a special commission that raised the possibility of a national ban on the practice in certain public venues - notwithstanding the extremely marginal number of women who wear it. In 2009 President Nicolas Sarkozy stated that the burqa is "a sign of debasement" and not welcome on French territory. Assembly member Bérengère Poletti asserted, "even if only five or six women were concerned, it would be a matter of principle" (Assembly hearings, September 9, 2009). The burqa, like the headscarf, which was banned in French public schools in 2004, is treated as a violation of laïcité (French secularism) and of equal rights for women as well as an indication of sectarianism - and thus, a violation of citizenship (Joppke 2009; Amiraux 2008; Killian 2007; Salvatore 2007; Scott 2007; Bowen 2006; Stemmann 2006; Strieff 2005; Césari 2005). The state and larger French public, in its fixation on Muslim women's practice, has come to equate these women with contradictions to republican liberalism (Joppke 2009) and has politicized their otherwise insular religious practice. Indeed, Salafist Islam more generally, or the form of Islam practiced by most women who wear the burqa, is thus explicitly tied to the twin evils of "communautarisme" and "Islamisme" (Assembly hearings 2009; Delore and Dubois 2004; Kaltenbach and Tribalat 2002). The Salafist movement, increasingly prominent in poor neighborhoods in France, refers mostly to a set of practices as opposed to a set of organizations. The desire and attempt to emulate the Prophet Muhammed and follow the teachings of the earliest generations of Muslims is at the heart of the larger movement. ${ }^{2}$

Much of the recent academic literature that has sought to understand Islamic Revivals (including Salafist Islam) or more specifically, Muslim women's piety movements that have incorporated stricter veiling standards, has challenged the narrow liberal assumptions and orientalist fears that underlay disdain for a personal ethical practice as the burqa (Mahmood 2005; Abu-Lughod 2002; Khan 1998). However, rather than problematizing the politicization of religious practice, the literature has insisted that everyday piety and ethics is inherently a form of politics (Hirschkind 2006; Mahmood 2005; Wenman 2003; Warren 1999; Connolly 1995), that it represents a political imaginary and nurtures political demands (Tuğal 2009). This paper questions the politicization of Islamic Revival movements first, by pointing out the normative stakes of different definitions of politics - as either based on ethical practice (as per the more recent trend) or on traditional forms of direct engagement with the state. In the case of Salafist women in France, the stakes involved with viewing the burqa as a political act are the impacts of state regulations of this deeply private domain of religious practice. Even beyond the question of stakes, however, neither approach to politics describes this form of Islamic Revival in France's working-class banlieues. ${ }^{3}$

Based on ethnographic fieldwork in a women's mosque community in Les Minguettes, a poor neighborhood in a banlieue of Lyon, I argue that Salafist women are not practicing a

\footnotetext{
${ }^{2}$ Historically, the Salafist movement refers to a reform movement within Sunni Islam to return to the original teachings and practices of the Prophet Muhammed and the Quran. Its origins as a movement are debated, with some citing 18th century Arabians and others citing 19th century intellectuals in Egypt. It is also internally debated as to which Islamic groups, schools of thought, and practices, may be considered Salafist. Salafism has historically been a pietist and apolitical movement, after some involvement in state politics in the late 19th and early 20th centuries (Stemmann 2006). See Euben and Zaman (2009) and Hourani (1983).

${ }^{3}$ The term "banlieue" refers to the suburban peripheries of France's urban centers. For an analysis of the socio-political construction of the 'problem of the banlieues' in France, see Tissot (2006). See Wacquant (2008) for an analysis of the differences between French banlieues and the American ghetto.
} 
form of politics but rather, a form of "antipolitics." Antipolitics refers to the rejection of state engagement in favor of the valorization of private life, as a substitute for democratic political participation (Renwick 2006; Goven 2000; Havel 1985; Konrád 1984). It was theorized in the 1970s and 80s by the dissident opposition of Eastern Europe toward the constitution of autonomous civil societies. I present three major phenomena that define the antipolitics of the Salafist women's movement. First, the women are engaged in a struggle to defend, expand, and reconfigure the private sphere against the intrusions of the state. Second, they are building a moral community to support each other through the economic and social ostracization they all face. Third, they emphasize their spiritual conditions and state of serenity above material life. All three of these defining characteristics were also central to the original conceptualization of antipolitics.

All of the women I met in the mosque community of Les Minguettes freely chose to wear the djelbab or niqab, sometimes even against the wishes of their husbands and families. Thus, the state's interest in prohibiting the burqa on the grounds of women's oppression is immediately problematic. ${ }^{4}$ To an extent, their antipolitics rejects both state and family authority, reconfiguring their private spheres toward their own self-practices and recognizing the high stakes of ceding the personal domain to the political.

In the following discussions I examine the politicization of Islamic Revival movements by both state and scholarly discourses. I then outline the different conceptions of politics used to explain Islamic movements, the stakes involved with these different conceptions, and why the notion of antipolitics better fits poor women's piety in France. The rest of the paper presents the three main components of Salafist women's antipolitics: the reconfiguration of the private sphere, the retreat into a moral community, and the achievement of serenity in a life defined intrinsically by suffering ("la vie musibah"). ${ }^{5}$

This paper contributes to literature at the intersection of Islam and political sociology by presenting a third way of characterizing Islamic social movements, beyond the categories of political or apolitical moral reform. It also interrogates the implicit understandings of the meaning of politics and thus the assumed connection between political Islamic movements and piety movements. Finally, it provides a crucial empirical contribution by presenting the actual teachings and practices of a group of women widely talked about but whose own voices have been ignored (Chouder et al. 2008). In so doing, it takes seriously the context of poor people's explicit rejection of politics.

\section{Politicizing Islamic Revival: From "Communautarisme" to Politics of the Self}

The politicization of the burqa follows a longer trajectory of what several scholars have described as attempts by the French state to exclude and stigmatize its post-colonial subjects while simultaneously detracting attention from its larger-scale crises of the welfare state (which disproportionately impact Arabs in the country's deindustrialized suburbs) (Amiraux 2008; Tissot 2008). From the colonized Other to today's potential terrorist, French Muslims have been stigmatized in numerous ways (Bacchetta 2008).

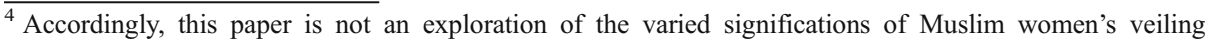
practices or whether or not the burqa constitutes oppression of women. For an overview see El Guindi (1999); Ahmed (1992); Macleod (1991); Abu-Lughod (1986); Mernissi (1985).

5 The phrase, "la vie musibah," combines French and Arabic and was used by the mosque teachers I knew. I translate this generally as "[a] life of suffering" though the Arabic term, al-musibah, is translated typically as "disaster" or "catastrophe."
} 
This trajectory of stigma is linked to the colonial era and to the history of French immigration. Workers from the Maghreb began migrating in the 1950 s and 60 s to meet French labor demands and post-War reconstruction needs (Laurence and Vaisse 2006). France restricted immigration and ended labor recruitment in 1974, however, the foreign population increased because of family reunification and illegal immigration facilitated by French employers. There has since been a steady trend toward restricting immigration and citizenship for North African migrants. Moreover, the severe decline in France's manufacturing jobs since the 1970s raised popular anti-immigrant sentiment as well as eliminated traditional vehicles of immigrant assimilation. The political activism that existed in the working-class banlieues was thus historically about immigrant rights. But it is important to bear in mind that religious rights were intertwined with these debates long before the post-9/11 era. For example, the issue of Islam first gained salience in French politics in the mid-1970s with a series of rent and labor strikes in the immigrant hostels and car factories. The workers' demands, which included space for prayer, were dismissed as the result of manipulation by religious fundamentalists (Cohen 1997, pp. 110-111).

As many immigrant families lacked the mobility to exit the housing-projects, the category of "quartiers sensibles" (sensitive neighborhoods), as a constant threat to security, became virtually synonymous with Arabs and Muslims. The focus on unemployment and discrimination disappeared (Tissot 2008). Central to the trajectory of stigma has been the discourse around communautarisme, derogatorily associated with Muslims and Islamic practice. Most generally, the French conception of 'communitarianism' refers to ethnic or religious sectarianism and submission of individual will to community authority (Salvatore 2007). It is through the lens of communautarisme that the French state and public view the burqa foremost as a symbol of women's oppression at the hands of Muslim men in their community (Joppke 2009) and further, as a security threat hidden behind discourses and norms created in the basement mosques of les quartiers sensibles.

The banning of the headscarf in public schools was precisely a move by the state to assert its authority against the supposed tide of communal pressure among Muslims, in an institution designed for the molding of French citizens and protection of laïcité (French secularism) (Baubérot 2006). While the law was designed to protect laïcité in schools, teachers, and schoolgirls, it also clinched the larger public discomfort with the headscarf as a sign of religion in public space and symbol of women's oppression. The niqab, a different and more "extreme" practice than the headscarf, carries this discomfort much further. In 2008, a Moroccan woman married to a French citizen was denied French citizenship on the grounds of her wearing the niqab and thus "failing to assimilate" and rejecting the values of the Republic. It was the first time religious practice was used to refuse nationality.

Deemed a "mobile prison," the niqab is also considered a threat to security and public order (Assembly hearings, September 2009). Although its association with terrorism has not been explicitly cited, its ties to the growing Salafist movement, centered largely in declining and stigmatized banlieues, are clear and discussed extensively in the Assembly hearings. This form of "fundamentalism" is described in terms of a radical separatist political project. While the Salafist movement is avowedly apolitical, it is accused of creating sectarian "hate" by its rejection of liberal democratic principals that leaves its members vulnerable to terrorist recruitment (Stemmann 2006). The niqab, in particular, is implicitly categorized with this vulnerability in that it represents the rejection of French values - liberté, egalité, et fraternité. Women in niqab cordon themselves from others and embody their separation and inequality with men. The burqa is thus the target of those who fear "communautarisme" and "Islamisme" as threatening to destabilize the secular Republic (Gerin, National Assembly hearings, September 16, 2009). 
Since the start of France's "headscarf affairs" many scholars have critiqued the assumptions that underlay the 2004 ban, asserting that the headscarf is not a mere "symbol" of religious expression but rather, an essential part of oneself (Asad 2005), or that its patriarchal essence is no more so than that of French sexual and gendered norms (Scott 2007; Butler 2006). More broadly, Saba Mahmood's (2005) work on women's Islamic Revival has questioned the type of assumptions of liberal feminist theory that clearly underlay the rationalization for the headscarf ban. Her work in Egypt presented the hermeneutics of the women's piety movement and challenged assumptions within liberal theory about agency and freedom, key concepts employed in French debates on Muslim women. While Mahmood (2005) agrees that the women's movement cannot be understood as part of a liberal project (and questions why it bears the burden of proving itself compatible with liberal theory), she argues that liberal assumptions undermine the ability to "envision valuable forms of human flourishing outside the bounds of a liberal progressive imaginary" (p.155).

Mahmood and others writing in this vein have worked toward a greater understanding of women's Islamic practice that remains otherwise shrouded by terms and concepts such as freedom, resistance, and subordination. But further, they insist that liberal political theory has marginalized the realm of religious ethics, the type practiced by women's piety movements. Instead of separating ethics from politics, they argue, ethics must be understood as critical to public life and politics as they underlie modes of reasoning and assessment and reveal something about the "political landscape" of Muslim societies (Hirschkind 2006). In her study, Mahmood shows how rituals of bodily behavior that are central to the Islamic Revival reveal different visions of self, community, and authorityand these visions influence Egypt's Islamist movement. Bodily practices are not just symbols used by social movements but crucial paths to realizing the self (Mahmood 2003). In his work on Islamists in Turkey, Cihan Tuğal (2009) corroborates this understanding of social movements and everyday piety. Tuğal uses the case of Islamists in Turkey to argue that the state is intrinsically part of the formation of subjects and their identities and moreover, that the state is transformed and challenged even in the absence of traditional forms of political protest. The Islamization of society, through religious debates, sermons, organization of time and space in alignment with daily prayers and sex segregation, ultimately creates subjects who desire political change in favor of Islam and pious leaders. The state, of course, is forced to react to these deep changes in civil society. "As a result," as Mahmood (2003) writes, "it is very easy to miss the political implications of the piety movement and to regard them, as many scholars have done, as movements of moral reform that seek to bring about change in social mores but have little to reveal about the political landscape of contemporary Muslim societies" (p.861). The recent literature on Islamic Revival thus draws upon a fuller conception of politics, one that includes everyday practices of sociability, comportment, and moral reasoning rather than traditional forms of state-centered action. In sum, politics is no longer just about the state but also an enactment of one's self and one's identity. In this tradition, the development of women's Islamic Revival represents an important political moment.

\section{Conceptions of Politics and Antipolitics}

We should expect a concept of politics to clarify our normative intuitions about the practices we call political, which in turn define objects of explanation as normatively significant. Because normative interests are inherent in defining the objects of 
explanation, any conception of politics will be, as William Connolly (1983: Ch. 1) has argued so nicely, 'essentially contestable.' The point of definitional clarification is not, then, to insulate a definition from contest, but rather to clarify its normative stakes. (Mark Warren 1999, p. 209)

My argument in this paper is informed by Warren's and Connolly's assertion that all definitions of politics are contestable and require clarification of their normative stakes. In this section, I explore the stakes of the two major conceptions of politics used in the literature on Islam and explain why the framework of antipolitics best fits the case of Salafist Islamic Revival in France.

There are two conceptions of politics generally used in explaining Islamic movements. The first conception, described above, is that of politics as ethical practice. This focus on a "politics of the self" comes out of the normative interest in exploring mutual coexistence and "toleration" of difference in plural democracy (Brown 2008; Connolly 1999). With such a definition of politics, the desires and moral reasoning within piety movements would be taken seriously in public debates as opposed to being seen as an invasion of irrational sentiments into the secular public sphere. ${ }^{6}$ This further fits with the historically feminist and post-Marxist notion of politics that recognizes non-state loci of authority, such as religious institutions and the family (Warren 1999, p. 213) (as per the feminist statement, "the personal is political"). ${ }^{7}$ But it also, I argue, becomes perverted and invites paternalistic state regulation of ethical practices that are consequently viewed as influential and critical to the functioning of the polity. The second conception of politics centers on the state and was implicitly used in the literature on Islamist political parties and political organizations. ${ }^{8}$ The decline of activity targeting the state, and the imploding of many Islamist parties around the globe has led many to declare "political Islam" a dead or failed project (Roy 1994). This narrower, Weberian approach would theoretically limit state interest to movements that make claims of the state or seek its transformation. But in doing so, it also privileges the discourse of formal, often unrepresentative, institutions and ignores informal practices among those who have little access to the state.

Using the first conception of politics, it is difficult to argue that Salafist women in France are not engaged in a form of politics - if individual and regimented bodily practices and conversations about ethics, such as theirs, are central to shaping social visions (Eliasoph 1998; Arendt 1958). I point out only that this politicization is effectively aligned with the state's portrayal of personal practice (i.e. the burqa) as public and thus invites state interventions. Using the state-centered conception of politics, I argue that the French Salafist movement has a very weak and constrained potential to influence the political sphere and can thus scarcely be considered a form of politics. First, any claims of the state are systematically limited by the status of Salafists as minorities (within a religious minority) in a secular state. Right-wing fears of a "sharia state" have little empirical basis, as there exists no possibility for a religious political party and no Muslim National Assembly members. ${ }^{9}$ The major Islamic institutions such as CFCM (Le Conseil Français

\footnotetext{
${ }^{6}$ Scholars emphasize ethical practice, further, as an acknowledgement that states have increasingly made religion a domain of regulation and thus, a matter of politics (Hirschkind 1997).

${ }^{7}$ It also seeks to dovetail with Foucault's later work, inspired by the Iranian Revolution, on "self-realization as a revolutionary act" (LeVine and Salvatore 2005a, b).

${ }^{8}$ While the literature on political Islam was mired in definitional debates, most scholars agreed that "political Islam" was activity targeted at the state. See Karam (2004); Burgat (2003); Nasr (2001); Beinin and Stork (1997); Esposito (1997); Riesebrodt (1993); Ayubi (1991).

${ }^{9}$ The Parti des Musulmans de France (PMF) was created in 1997 and participates in a few local elections. Candidates usually gain no more than $1 \%$ of votes.
} 
du Culte Musulman) and the Paris Mosque (La Grande Mosquée de Paris) are further heavily controlled by the state. Second, Islamic civil societies in many of France's banlieues are weak, most having collapsed in the last decade (Césari 2005; see Levy 1999). Salafist women's lives are also relatively isolated and circumscribed by the spatial structures of the housing projects and policies against the headscarf which have barred them from educational and employment opportunities. While the mosque activities of Salafist women may constitute the creation of a civil society (that could be mobilized against the state), it is weak because their discourses are not of a public character and because they lack a certain degree of social trust (see Putnam 2000).

Politicizing Islamic Salafist Revival, using either definition of politics, is thus problematicthe former definition leaves no analytical space for a private sphere; and the latter severely overstates the abilities and desires of poor Salafists to access the state. I argue that instead of practicing an intrinsically political act, Salafist women who wear the niqab or djelbab are engaged in a form of antipolitics. While there were different variants of antipolitics and dissident thought more generally, I use here the radical version of the movement which rejected all forms of state engagement and actively rejected being labeled as political (Renwick 2006). It should also be noted that Hungarian writer George Konrád (1984) distinguished antipolitics from "apolitical." He argued that apolitical individuals were merely "dupes" of professional politicians, the "young people who can always be brought out for parades" (pp.227, 231); antipolitics, in contrast, implies a degree of conscious opposition to the political realm. As one of the main theorists of antipolitics, Václav Havel wrote:

I believe the phenomenon of dissent grows out of an essentially different conception of the meaning of politics than that prevailing in the world today. That is, the dissident does not operate in the realm of genuine power at all. He does not seek power. He has no desire for office and does not woo voters. He does not attempt to charm the public, he offers nothing and promises nothing. He can offer, if anything, only his own skin - and he offers it solely because he has no other way of affirming the truth he stands for. His actions simply articulate his dignity as a citizen, regardless of the cost. (Wilson 1992, pp. 320-21)

There are three phenomena of today's Salafist movement in Les Minguettes that I argue define its antipolitics. (1) Salafist women are engaged in a struggle to defend, expand, and reconfigure the private sphere against an intrusive state that seeks to "protect" Muslim women and the public sphere. As Konrád (1984) wrote of antipolitics, the movement sought primarily to expand the boundaries of the private sphere, in a world where every facet of life, from intellectual to free time, was considered political (pp.202-204). In this case, the burqa is part of one's private sphere, in the sense that all matters of the self and body (along with family and intimate relations) are understood as private (cf Scott and Keates 2004). But the state insists its presence in public space impacts society for being anti-social and sectarian. In a sense, the women believe that the burqa is part of the private sphere that they must inherently practice outside the home. I argue that they are seeking a sort of inversion of the private sphere-toward one that is de-territorialized and that is defined more through social interaction and less by physical space (see Dupret and Ferrié 2005). The burqa represents their private relationship with God, but it must be practiced wherever they share physical or social space with men (other than their husbands, fathers, fathers-in-law, or brothers). (2) Salafist women in Les Minguettes are prioritizing a moral community of mutual support in the face of ostracization. Antipolitics was further theorized as a retreat into "unorganized private life," presumably including families and friendships (Konrád 1984, pp. 204-206). However, unlike the picture of Hungary taken for granted by 
Konrad (Goven 1993), family life per se is fraught in Les Minguettes, and the mosque community is sometimes a refuge from both an oppressive state and family. Thus, one's individual relationship to God is more important than community and even family. (3) Spiritual conditions and the achievement of serenity are more important than economic and all other matters. The teachings at Mosquée Hasan are oriented toward inner faith and serenity as the key to an Islamic path. The concept of antipolitics also elevated spiritual work, "truth," and "dignity" (Konrád 1984, p. 230) -inner states of being that could avoid the heavy hand of the state.

\section{Data and Method}

The research employed in this paper is part of a larger project on the relationship between "Islam of the banlieues" and middle-class Muslim associations that seek to engage the state. The data presented here is from ethnographic fieldwork conducted over 10 months in two housing-project mosques in the neighborhood of Les Minguettes, located in the suburb of Vénissieux. Vénissieux is located outside the city of Lyon, in east-central France. Lyon is the second largest metropolitan area in the country. Historically, Vénissieux was a city of heavy industry, linked to the automobile industry, and overwhelmingly working-class. Les Minguettes is where the nation's first visible lower-class riots ("rodéos") erupted in the 1980s (Dikeç 2007). Thereafter, it became a symbol of the "malaise" of the declining peripheries of French cities.

Both of the mosques I studied in Minguettes came under attack by the state after September 11 and are attended largely by Salafist men and women. Most of the teachings and interactions I describe are from women's weekly classes at Mosquée Hasan. ${ }^{10}$ Because I focused mainly on women who attended the mosque, the study excludes those who practice Salafist or other forms of Islam but choose not to associate with mosques.

There are approximately 50 women who regularly attend Mosquée Hasan. Most are from North African immigrant families but were born and raised in France, and nearly a quarter to a third of the women are French converts to Islam. Nearly all live either in the poor suburb of Vénissieux, in which Les Minguettes is located, or a neighboring suburb. All wear the djelbab, and several wear the niqab. Most are in their 20s or 30s, with several older women and a few teenagers. The Mosquée Hasan classes were dynamic, with a mix of lectures and student discussions, and there was often an air of excitement about learning that kept the women coming back every week.

Initially, I faced mistrust and numerous barriers to entry into the religious spaces of Les Minguettes. I describe the context of extreme distrust of outsiders in the following section. As my middle-class informants in Lyon had no contacts in the neighborhood, I took to wandering around the housing projects myself, with a combination of naivité and impudence. When I introduced myself as an American student to a café owner, he proceeded to yell at me for several minutes, listing the many reasons he could not trust me. I persisted in my efforts to find individuals willing to speak with me and eventually gained entry into one of the two mosques I studied. Through trial and error and the malleability of my own identity, the tensions I encountered gradually gave way, and I built contacts through the two mosques. Two things typically worked against me: being American and a researcher. However, after the election of Obama in 2008, I sensed a decrease in the stigma attached to being American. Additionally, when the women I knew learned that the headscarf was not banned in the U.S., they seemed to warm up to the possibilities of American identity and politics.

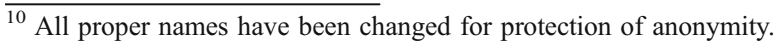


Three things worked in my favor: being a woman, South Asian-American, and of Muslim background. I learned to be as ambiguous, while remaining honest, about my identity as well as the details of my personal relationship to Islamic practice and veiling. To my surprise, I met many French people, whether Muslim or non-Muslim, who possessed an amusing, almost orientalist, fascination with India. They seemed to immediately forget that I said I was American or a student studying Islam in France, and instead ask questions about Bollywood films, Indian dance and cuisine. I was thus an outsider, but welcome. To say that my experiences in India were critical to gaining entry into Les Minguettes might be an overstatement but nonetheless bears some truth.

Being a woman was basically a requirement for entry among Salafist women, in a world marked by fairly rigid sex segregation. A shared Muslim identity and understanding of their social marginality was also critical. I had enough knowledge of Islam to participate in prayer and mosque activities, fasting during Ramadan, and reading Arabic. With regard to my dress, I wore a long Moroccan robe and hijab as my uniform. Wearing a light brown color and floral print, I stood out among the other Salafist women, dressed mainly in black or blue djelbabs. But no one ever proselytized or questioned my dress. I had worn the djelbab and niqab in other countries and research settings but chose not to in France, simply because I could not even manage the social isolation I felt and the glares I received in public merely from wearing a headscarf. Learning to dismiss others' perceptions of me in this uniform was a primary and continual struggle throughout the ethnography.

As my presence in the mosques became familiar, and I no longer seemed an intruder, I came to know many housing-project residents in the neighborhood and attended the mosques several times a week. I discreetly recorded the Friday qhutbas (mosque sermons) and took hand-written notes during the mosque classes alongside the other women. I came to know 10 Salafist women very well and spent time with them outside of the mosque setting, in their homes and at family gatherings. I also regularly visited, in public places, with 3 men of housing project mosque communities. There were numerous others with whom I had conversations about life in the declining, working-class banlieues and their experiences with Islam in France. I wrote daily field-notes but was generally unable to digitally record conversations or semi-structured interviews, as per my informants' wishes.

\section{Reconfiguring the Private Sphere}

The recent history of state intrusion into Les Minguettes has left most residents suspicious of outsiders and jaded. The larger suburb of Vénissieux has become associated with the growth of Salafist Islam alongside state intrusion. Indeed, Deputy André Gerin, who initiated the national commission on the burqa, is the former mayor of Vénissieux. Gaining entry into the mosques was thus a painful, arduous process, thanks to years of police surveillance and security efforts. Until I adjusted to this, it felt difficult to just be normal. I grew tired of the ubiquitous EuroSecurite guards on the bus and at the terminals. On several occasions, they would stand right next to me and smile at me on and off for an entire bus ride and then walk right behind me as I got off the bus. For the members of the mosques, memories of police raids, arrests, and deportations of mosque leaders were fresh. Three major incidents have defined Les Minguettes in the last decade. The French arrests of two young men who were sent to the Guantanamo prison camp occurred in Les Minguettes. (They were returned to France in 2004 and 2005, convicted in 2007 of criminal association, and released on appeal in 2009.) There were the arrests of several family members who ran a housing project mosque. Their apartment was raided as they were accused of having ties 
to Chechen militants. Their mosque, which I attended during the fieldwork, was left unorganized and stained by its ill-repute. Finally, Abdelkader Bouziane, the former imam of Mosquée Hasan, was deported in 2004 for posing a threat to public order. This occurred after the publication of an interview with him by a city-based magazine in Lyon in which he discussed the right of men to hit their wives ("only below the face") in cases of adultery. He also made remarks about his desire for France to become an Islamic country. Notwithstanding Bouziane's problematic views, the magazine article was without context, and his remarks were made mostly at the journalist's prodding. But it caused an outcry throughout the country, and Bouziane was expelled from France after having lived there for 25 years. According to Ahmed, a former long-time Muslim activist in the neighborhood, "the whole community felt scared and demoralized." When I was doing my research at Mosquée Hasan a few years after the deportation, several people outside the mosque community told me with no doubt that there were state agents who attended the women's classes on a regular basis. I was initially incredulous that there was a spy among this group of women that I was coming to know. Eventually, when I saw the degree of privacy that each woman sought to maintain, it no longer seemed so outrageous. No matter how much we came to know and like each other, nobody ever really knew the private details of each other's lives. There was always an element of uncertainty and mistrust.

An underlying mistrust colored not only my initial entry into Minguettes and the general relationships inside the mosque, but it clearly defined the relationship to the state and law enforcement, as is well-known. One of my close informants, a Syrian woman who taught at "Mosquée Ennour," often complained about raising her daughter in a neighborhood like Minguettes. Sumaiya had the usual complaints, such as the weekly burning of cars. "But you know, I understand why [our kids] riot," she reflected on the harassment of minority youth in the neighborhood. "The police are constantly bothering them. We hear stories all the time, and I saw it myself." She relayed various local stories of mysterious disappearances and even murders of Maghribi (of North African origin) youth. "You never know, but I really think - many of us do- that it's the police."

Thus, Minguettes is known for its hostility to outsiders, researchers, and journalists, who on occasion have had stones thrown at them by neighborhood youth. The climate of stigmatization has led to resentment of those who might seem to treat the neighborhood as a kind of zoo, to be observed and photographed. In time, I recognized the distrust of outsiders and the social code that involved keeping things private and insulated. I was also told by a resident that women are perhaps even more distrustful of outsiders or researchers, for fear of inviting trouble for their husbands and sons. The phenomenon of mistrust follows the collapse of civil society and heavy state intrusion. Hence, the increased importance of maintaining and protecting a private sphere.

But it was not always like this in Les Minguettes. Although it has been part of the deindustrializing, undesirable urban periphery for decades, it also enjoyed a period of intense social activism and flourishing civic associations during the 1980s and 90s, under Mitterand's socialist administration. This included Islamic associations as well as projects initiated by secular associations such as SOS-Racisme and DiverCité, active on behalf of immigrant rights. France's first and largest national demonstration for immigrant and racial justice was initiated in Les Minguettes in 1983. The demonstration, called "marche des beurs" by reporters, followed a series of riots in the neighborhood after a local teenager was injured by a policeman. (The word "beur" is a slang term for the French-born children of North African immigrants. It was intended to reflect their simultaneous belonging and alienation from French and Arab cultures.) Although few recall this event today, the name Les Minguettes continues to be attached to the memory of 1983. "There was so much hope 
back then," recalled Ahmed. "Today, it's all gone. There's nothing." Ahmed's popular Islamic youth association in Vénissieux had once hosted weekly activities including family events, scholarly tutoring, youth clubs/sports and after-school activities, and training in debate and public speaking. According to Ahmed, as local youth began feeling politically empowered, their presence appeared more threatening to André Gerin, then-mayor of Vénissieux. In the aftermath of 9/11 this network of Muslim activists was attacked by the state and placed under surveillance, eventually leading to their decline. Ahmed, like a number of former activists, was blacklisted throughout Lyon as a fundamentalist and potential terrorist. His defense of the two brothers who were sent to Guantanamo led to greater notoriety for him and a public confrontation with Mayor Gerin in which other Muslims were pitted against him. His association collapsed and today, said Ahmed, "I have a family now, kids to support. I can't put my family at risk. For all of us, it became too hard to find work or even have respect. And I'm tired. I can't do it anymore." He mused:

What did we want when we were younger? To get out of the banlieue. To be le bon francais, avec la bonne baguette [a respectable Frenchman with a baguette under his arm]. Now, there are exactly two structures left in Minguettes: the drug dealers and the mosques. And the mosque leaders are totally incompetent and uneducated. They don't have the means to be politically active or organized.

Ahmed's particular trajectory reflects the decline of Les Minguettes, its structures of civil society and the hopes that bonded together Islamic (as well as secular) associations. It also shows the precise mechanisms by which the state itself demoralized and broke apart networks of youth and Muslim leaders, leaving only a drug market and unorganized mosques in their wake.

The state's regulation of mosques and Muslim activists also coincided with the banning of the headscarf in schools and a growing discourse about the oppression of Muslim women. Conversations in mosques or covering one's hair were no longer considered private matters. Indeed, the most recent step in eroding the private sphere has been attacking the burqa. This did not come as a surprise to any of my informants. As Sara, a close informant who wore the niqab, stated: "It's starting again." Given this history of state intrusion in the banlieues and monitoring of Islamic practices, defense of the private sphere is among the only responses available to poor Salafist communities. In arguing that Salafist women seek a de-territorialized conception of the private sphere, I mean that the burqa is a private practice of the self that the women seek to carry with them into public space. To the state, the presence of the burqa in public space is harmful to the public and to the women themselves for promoting sectarianism, fundamentalism, and violence against women (National Assembly hearings 2009). What the women wear in their apartments is the only domain that the state really concedes as the private sphere.

In addition to the notion of de-territorializing the private sphere, there is also a reconfiguration of the private sphere toward the self and away from the domain of family life. This is perhaps expected in a context of the disintegration of urban, immigrant families. While the state is eager to enter the domain of the Muslim family by insisting that men are coercing women into wearing burqas, Salafist women are rejecting both the state and men (or any other family members) as their agents of liberation. Their private sphere is strictly about their individual relationship to God and requires, if necessary, expulsion of both the state and their families. ${ }^{11}$

\footnotetext{
${ }^{11}$ This is in contrast to the antipolitics of Hungary, where, as Joanna Goven (1993) argues, women's domestic work allowed for men to participate in social and intellectual life. Antipolitics, in other words, worked primarily for men.
} 
Although this conflictual scenario in no way pertains to all of the women of Mosquée Hasan, it was not far into my research that it became abundantly clear that most of the women chose to wear the djelbab or the niqab-indeed, sometimes against the wishes of their husbands, parents, or brothers. While the question of whether or not women choose to wear the burqa permeates all national debates on the practice, many women of Mosquée Hasan were unmarried (and thus were not coerced into the practice by a husband) and/or came from non-religious families. Thus, the dominant trend at this mosque was precisely the opposite scenario that the French state and public continually evoke. For some women, misconceptions and disgust of the practice had painful personal consequences, especially when they occurred in the context of their own families. For example, Amina was a 29-year old woman of Algerian background, born and raised in France. Her particular story is full of regret and anxiety. Estranged from her family and currently unemployed, she lived alone in Vénissieux. Her family did not practice Islam, and her brother was abusive. She had minimal contact with her mother, who said to her (vis-à-vis her djelbab), "you think anyone's going to want to marry you, dressed like that?" Although of Muslim origin, her family mocked her religious practice and offered her no material or other support.

Contrary to the popular image, there are also numerous women who assert their desire to wear the djelbab or niqab against their husband's will. Ahmed, the former activist from Minguettes, recounted the story of his good friend: "His wife insists on wearing the burqa, and it's driving him crazy. He finds it completely embarrassing." During a session at Mosquée Hasan, one woman, perhaps in her mid-30s, broke down crying in front of fifty of us students. She had a scarf roughly tied around her hair and was wearing a tight Moroccan robe (instead of a dejlbab), unusual among most of the students at Mosquée Hasan. "My husband doesn't want me to wear the hijab. He insults it, constantly criticizes me for wanting to wear it. Others make fun of it too. And I have a job in the [Vénissieux] city administration. I have to take it off for work-I don't have a choice. I don't know what to do." Unable to reconcile her desire to start a rigorous spiritual and religious practice with her external constraints, she said she was growing increasingly depressed.

Malika, one of the teachers at Mosquée Hasan, was concerned and troubled but insisted that the djelbab (and at least headscarf) is not optional but is obligatory. Whenever such stories or questions came up, she was sympathetic but firm.

Remember, the Prophet's companions were always mocked and ostracized. They were even tortured. I can't be the judge of your decisions, but all I can say is that it's not a choice, we can't say no to God. You have to have courage to do what you believe. People laugh at me all the time. They get in my face and ask me aggressively why I do this. Try to explain very simply and directly, in a well-mannered way. But once they get aggressive or mock you, just leave it. Don't engage them. Just turn inward.

She then offered to give this particular woman the number of a sheikh in Saudi Arabia who could talk to her husband. (The general approach to these questions is to try every possible avenue to reconcile with one's spouse. If, ultimately, a husband obstructs his wife's Islamic practice, she has the right to demand a divorce.)

Salafist reconfiguration of the private sphere as increasingly oriented away from the family is also evident in the phenomenon of French conversions to Salafist Islam and "born again" experiences (Roy 2006). The standard line of explanation for the growth of Salafism is its appeal to the marginalized sons and daughters of immigrants in the declining workingclass banlieues (Césari 2002). Having suffered the loss of cultural identity and exclusion by French society, these young men and women are drawn to Salafism for the many ruptures 
that it demands and celebrates - a rupture from family ties, street culture, and French (nonMuslim) society (Roy 2006). Disaffected youth of working-class banlieues, even those without an immigrant background, do not feel part of any culture or society and welcome the redefinitions that Salafism imposes on one's life. ${ }^{12}$ It is argued that Salafi Islam in France reflects the detachment of ethnicity from Islam (Roy 2004, 2006). As Mélissa, one of numerous young French converties I knew, proclaimed: "I gave up everything. I left my family, everything I knew, when I embraced Islam."

This detachment of Islam from ethnicity is a dynamic process that is explicitly discussed in the mosque setting. For example, I witnessed the following discussion at Mosquée Hasan between Malika, who was teaching that day, and the students.

Student 1: What about a person who's Arab, Muslim, but doesn't pray or anything? But he fasts during Ramadan. Will he go to hell or heaven?

Malika: Nobody can say who goes to heaven or hell. But he doesn't believe? He doesn't have faith?

Student 1: No....

Malika: Then he's a kafr. There are Muslims with weak faith, and those who simply don't believe. If he doesn't believe in God, he's a kafr. It doesn't matter if you're Arab, or if your name is Muhammed or Abdullah.

Student 2: At another mosque I go to, the imam [mosque leader] said that we shouldn't label people who were born Muslim as "kafrs."

Malika: Right now in France, unfortunately, you just do as you want, regardless of sunnah [the way of the Prophet]. If he believes but also sins, well, we have no right at all to call him a kafr. But you think that a non-believing Arab is more Muslim than a practicing Muslim whose family was Catholic or atheist? I don't believe that at all.

In this discussion, Malika makes clear her position that one's ethnic status has nothing to do with being a "believer." What matters instead is the state of her/his faith. As Malika discussed numerous times in her courses, they cannot take for granted their status as Muslims simply because they were born into North African families. This is something that distinguishes the Salafist movement from "folk" Islam and also from middle-class discourses that take a more ambiguous approach to the question of defining who is Muslim. Another way to understand this phenomenon is precisely through the notion of reconfiguring the private sphere. The status of being Muslim, for Salafists, is not linked to embracing a public or extended family but rather, an inward orientation and set of beliefswhich are inherently private. Families often only stand in the way of one's private relationship to God. Thus, the defense and expansion of the private sphere against an intrusive and paternalistic state is crucial to antipolitics. But here, women are engaged in an antipolitics against both the power of the state and sometimes, their families.

\section{Retreating to the Lairs of a Moral Community}

It is ironic that the djelbab and niqab are perceived as a hostile rejection of sociability (National Assembly hearings 2009), when in fact the women who wear them are not only

\footnotetext{
${ }^{12}$ While my research in Les Minguettes corroborated much of this phenomenon, I place greater emphasis on the role of social exclusion and state hostility (above the role of globalization) in defining the context of Salafi success than do Roy and others.
} 
barred from secondary education and employment (not legally, but effectively) but also frequently subjected to social ostracization. Similar to the theorization of antipolitics, poor Salafist women were retreating into the "lairs" (Konrád 1984, p. 203) of a semi-organized, private community to find moral support and refuge from the politicization of their practice and further in this case, from conflicts with the men in their lives. Although many married women I met shared close emotional bonds with their Salafist husbands, there was a certain tension between men and women at Mosquée Hasan. The regular presence of numerous women at the mosque, amidst the very deliberate attempts to keep men and women segregated, produced problems from time to time. For example, several men were occasionally doing repair work on the mosque's façade outside the women's entrance, and there was a mutual annoyance that the gendered boundaries were being transgressed by each other's presence. I was told, second-hand, that a few men at the mosque resented the women's active organization and leadership at Mosquée Hasan.

As a form of antipolitics, Salafi Islam in Lyon's banlieues generally operates through informal networks of friends and is decentralized and lacks clear leadership, relying instead on teachers and sheiks. The individualized nature of Salafism is indicative of the retreat of the formal associations of civil society among poor Muslims, as personal and private relationships are favored. This parallels the antipolitical exhaustion with public associations that occurred in Konrad's time, where free time and socializing were practically owned by the state (Konrád 1984, p. 204).

From one perspective, it is the poor and disaffected backgrounds of many of these women that bonded them together and indeed, made them surprisingly welcoming to others. Although the women were isolated from much of society, their regular meetings at the mosque represented an attempt to build a supportive community especially in light of the marginalization they usually faced. The ethos of religious practice at both Mosquée Ennour and Hasan reflected this tension and sense of urgency. During prayers, for example, there was an obsessive focus on standing close together, shoulder to shoulder. At times I was nearly knocked over as women grabbed my arms, pulling me closer to them. I got the impression of a community huddling together, trying to protect itself. "There can't be any space between us [as per the Prophet's teachings]," I was told. "If we stay close together, the devil can't get past us." This sense of protection existed alongside the fundamental uncertainty and mistrust among the women that I discussed earlier. The women facilitated each other's spiritual path, shared teachings and ideas about Islam, and could empathize with each other over the stigma they confronted. All this was the case despite the absence of complete openness and trust.

The tendency toward refuge and support sometimes manifested itself through the phenomenon of spirit possessions, or possession by jinns. One Sunday, Yasmine, a young woman who regularly attended Mosquée Hasan, suddenly started speaking gibberish and shaking. This soon turned into screaming, weeping, tearing her clothes, and foaming at the mouth. Everyone was extremely frightened. Malika grabbed Yasmine and held her tightly. She loudly recited Ayat-ul-Kursi, an important verse and prayer in the Quran that is commonly recited for protection and blessings. Its recitation is thought to have the power to alter certain circumstances and diminish danger. With Malika firmly holding her, Yasmine calmed down. Malika explained that such evil spirits exist, though we do not know exactly why, and emphasized that we all had to sit closer together and surround this young woman in order to protect her. So the women moved further inward, forming a tight circle on the floor. The next week, Amel, another student, collapsed backwards onto my lap and was quivering and weeping. Even after we all worked to calm her, she continued to moan and fall over the next two hours. 
The teachers repeatedly explained:

This sister is very sick. Just as God created humans, he also created a parallel race of spirits that we can't see. They come here precisely to scare us, to stop you from coming here. But inshaAllah [God willing] you will continue coming to the classes.

Don't have fear of this sister, just pray for her.

I gently broached the subject with Nasreen, a woman who had some training in exorcism (roqaya). "How do we know [Amel] doesn't just have some illness in her head?" "No no, that's not Amel who's moaning and shaking, it's the jinn. Amel isn't actually like this in everyday life. But look what courage she has to keep coming here. I had a friend who was coming to the classes last year when she got possessed. She got so frightened and couldn't handle it. She left and never came back." My own bias was to consider these episodes as a physical release of stress, a channeling of personal stress into a more religiously acceptable form that then attracts attention and sympathy. But whatever the reality, these episodes clearly served to tighten the community, as we were all encouraged to keep coming to the mosque and to sit closer together.

While the women gave and received moral and religious support, there was little they were able to share in terms of their material prospects. Because of their djelbabs, Salafist women in Minguettes faced both economic and social ostracization. Few employers hire women who wear the hijab, let alone the djelbab. The reality of unemployment, especially for the unmarried women, was an everyday obstacle and source of stress. Most of the unmarried women I knew were searching work as domestic workers, one of the few jobs in which they might be allowed to wear their hijabs or djelbabs. Amina, presented earlier, was searching for work and growing increasingly depressed by her situation. She would often convey to me the benefits of rigorous Islamic practice but was mortified to admit to me one day that she couldn't quit her cigarette addiction because of her depression. One Ramadan night at the mosque she had to slip out to have her cigarette. (The status of smoking in Islam is unclear. Mainstream Muslims do not consider it sinful, while the Salafist community I knew claims it is sinful for being wasteful and unhealthy.) I found myself in an odd scenario, following her in the dark and rain to find a secret place where she could indulge. We whispered in the dark outside an apartment entrance, she in her black djelbab and with her pack of Marlboros. I then found myself having to spray her djelbab with an entire half-bottle of eau-de-toilette to cover up the smell. "What can I say," she said. "I'm depressed. I don't have a job, I'm alone, so I sit around all day and chain-smoke. We all have our own path. But please, don't tell anyone at the mosque." With Amina's financial troubles, she was anxious to marry so that she could depend on a spouse to work. Marriage, although encouraged more generally in Islam and especially among Salafists, represented a practical solution to the impossibility of working and wearing the hijab. If gossip spread that despite appearances she was in fact a chain-smoker, her reputation in the mosque communities would be tarnished and she would have trouble finding a husband.

Amina was able to subsist on her unemployment benefits after being laid off by a telephone company, but the benefits were to terminate in a few months. She would then live on welfare assistance of 450 euros per month, and her rent was 250 euros. She was starting to worry as the deadline was approaching, "but then I remember that God is guiding me and I shouldn't have fear. Malika always tells us not to worry, to trust God. That's what I'm trying to do. It always feels good to hear her say that." Amina, like several other women, had come to depend on the moral support and weekly routine of coming to Mosquée Hasan. When classes were occasionally canceled, she was exceptionally disappointed. 
The economic exclusion poor Salafist women experience is also related to their estrangement from the education system. A significant number of young women I met at Mosquée Hasan had dropped out of high school when the 2004 law against the headscarf in public schools was passed. While taking the metro after class, I had a conversation with Fatima, a French-Algerian woman who dropped out of high school after her first year. We spoke softly in each other's ears, two pariahs well-attuned to others' perceptions of us.

Parvez: I hate being stared at like this. Do you find it difficult?

Fatima: Yes of course. But I don't even see it anymore. I don't feel bad anymore. This is really something beginners feel. In the beginning I used to see it, they thought I was weird, or crazy. Then I realized that it's them. They're the ones that are crazy, that have a problem.

Parvez: Was it your decision to drop out of school, or your parents'?

Fatima: It was me. I got tired of taking [the scarf] on and off [at the entrance to school], and I started feeling really uncomfortable. I explained to my mom that I didn't want to go anymore. She was disappointed, but she understood. You know there's been a crisis here over the last five years [over this issue]. So I just dropped out. I fell out of touch with the world of school and students. But I actually started working as a housecleaner with a bureau [in the banlieue], and I don't have to take off my hijab. I know how things work now, and I can navigate the world of work. My life is full. I have free time, but I stay busy with my Islamic study.

At 22, Fatima had already gone through years of personal struggle over her decisions and gradual turn toward a rigorous Islamic practice. She took some pride in earning money as a housecleaner, but even this was fraught, as she complained to me that the other women with whom she shared her duties were rude to her. "One of them is a Maghrebine [of Algerian origin and non-practicing Muslim]. Sometimes they're the worst. She sneers at me while we work. I try to ignore her. I'm trying to transfer to something where I can just work alone, in peace." Fatima's sense of alienation from French society was something she balanced with her study of Islam. The courses at Mosquée Hasan provided consistent structure and meaning to her. "Twice a week is good, twice a week is okay," she mumbled to herself as we were driving to her apartment: two sessions were just enough to carry her through each week.

For Fatima and her older sister, Sara, who also quit high school, their intensive study of Islam was an important and satisfying replacement of their secular education, but they would have liked to have finished high school or pursue a university education if their religious practice was tolerated. During one of the classes at Mosquée Hasan, a student asked to what degree it was acceptable to pursue science and higher studies in the absence of the larger goal of promoting Islam. The teacher had been discussing the compatibility of scientific knowledge with Islam. She gave an ambiguous response to the question, citing "only God knows [the relationship between worldly knowledge and spiritual advancement]." "But we all know," the teacher reminded everyone, "that for us [in France], it's not even an option."

Alongside the marginality of unemployment and poverty is the constant social stigma of wearing the hijab. Being stared or jeered at in public, on the streets or in public transit, is an experience to which all of the women I knew became accustomed. I witnessed this on numerous occasions. For example, I was walking to a grocery store with Sabine, a French convertie who wore the djelbab. Her exceptionally petite frame often appeared drowned by her brown djelbab. She stood out in public, but she seemed nonchalant to the many stares she would get. We were standing at a pedestrian crossing in Minguettes when I saw two men in a truck pointing at her and laughing. I felt infuriated, but she didn't care. On another 
occasion, I was waiting for the tram with Amina and Nasreen, both of whom wore the djelbab. A woman physically pushed Amina as she was about to board the tram. I was confused as to what exactly happened and was in disbelief. "You really think it's because of your djelbab?” I asked. “Absolutely, there's no doubt. She's just trying to provoke me. They really have hate." She and Nasreen explained for my benefit that this was simply part of their everyday lives.

Fatima's older sister, Sara, had a particularly strong sense of upset with the attitude toward Muslims in France. Sara in fact chose to wear the niqab and would thus be directly impacted by any possible banning of the burqa. A week after I had met her, one of the local banks in Minguettes put up a sign on the door with an image of a woman in a niqab with an $\mathrm{X}$ through it. Sara remarked: "I was expecting this. But what's most upsetting is that it's other Muslims who are doing this. They're sell-outs. I hate the fact that they're the ones who represent us [to the state], who speak for us. Actually, they don't represent us [in the banlieues] at all." Sara was criticizing the few Muslim associations and institutions like the Paris Mosque (la Grand Mosquée de Paris) that announced their support for the commission to debate the burqa.

Both Sara and Fatima remember clearly the attacks on the hijab when the 2004 headscarf law was being debated. I asked Sara what she would do if there would ever be a ban on the burqa either in public institutions or elsewhere. 'I'm going to get out of here. My husband and I are looking into getting a house in Algeria. We can't take it here in France anymore. I spent a year in Egypt a few years ago and was so much happier being in a Muslim country." Over time I lost track of the number of women who claimed they were exhausted with their stigma and would be happier in a Muslim society. As Fatima said, "ultimately, we have to move back to a Muslim country. You see the way people look at us and hate us. Why put up with that?" When I asked her if she would miss France, she reflected for a moment. "Yes, I'll miss the euro," she said. "But then I don't need much in life to be happy." She laughed, "our parents left Algeria for France, and thirty years later, their kids want to leave France for Algeria." While many Salafist Muslims do find ways to emigrate to places like Egypt or Yemen, at least temporarily, for others it's not realistic. As Fatima admitted, adjusting to a poor country like Algeria might prove too difficult despite the poverty and marginality they experience in France. Interestingly, when Fatima left to spend the month of Ramadan in Algeria, she was contacting me nearly every few days inquiring about the group and classes at Mosquée Hasan, which she was sorely missing. Students like Fatima had come to depend on the teachings that became central to the creation of this moral community and, I argue, to the public disengagement and autonomous refuge that defines their antipolitics.

\section{Achieving Serenity in a "Life of Suffering"}

In this section I present the prevailing themes of several months of the women's classes at Mosquée Hasan. I found that these were largely oriented toward patience (sabr) in the face of suffering and how to find happiness in a life defined intrinsically by suffering (la vie musibah). In my experience with both middle-class mosques and Islam in working-class banlieues, this focus on life's temporality and the fact of suffering was unique to the Salafist community in the poorer mosques. With the absence of strong Islamic civil societies in the banlieues, major obstacles to economic stability, and disintegrating families, the mosque's continual messages of patience ( $s a b r)$ and serenity spoke directly to the bleak situations of many of the women. This clearly reflects one of the main existential positions that had characterized the antipolitics of Eastern Europe: decent spiritual conditions and the quest 
for individual truth were key to maintaining dignity in the face of a corrupt and overwhelming state (Renwick 2006). Antipolitics was not about hope for the future but rather, "respect for the present" (Konrád 1984, p. 185), valorizing the private, and "push [ing] the state out of our nightmares, so as to be afraid of it less" (p. 230). For Salafist women, trusting divine will, and thus developing serenity, was presented as key to augmenting one's faith. This often served the purpose of alleviating the women's anxieties and regrets. "Everything is in God's hands," Malika would say. "Once you accept this, apply this, stop living in the domain of the imagination [imaginary fears], then you can sleep in tranquility," she'd say with a lull (tu peux dormir traaaaanquil...).

In order to achieve perfect faith, one must continually work to reform her heart and in doing so, she privileges her private and inner state. Indeed, the private and personal nature of one's faith was often emphasized: it was considered prohibited to boast about one's Islamic practice such as fasting and charity or to even assume that one has purity of heart. ${ }^{13}$ Wearing the djelbab was viewed as obligatory but no guarantee of one's inner state of faith. Contrary to local stereotypes of Salafists as obsessed only with outward practice and vesture, Malika stated to me, "Look, I never judge anyone for their practice. I don't know why others think we're obsessed with the djelbab. It's only one practice. You can have the perfect outward practice but have no faith, and vice versa."

The ultimate goal of reforming and "nourishing" one's heart, attempted through prayer and practice, was feeling love of God. This was the key to having complete faith as a Muslim. The feeling of love is a nebulous concept in this context, and the women frequently asked questions about what it meant. The teachers emphasized that it is never a simple matter of outward practice, but rather a state of heart that one achieves or with which one might be blessed. Deep compassion, for example, exists in the heart and is an important religious virtue that reflects love of God. But no one really knows the state of her own heart, or that of others. Dalel, one of the teachers at Mosquée Hasan, repeatedly told the story of a Jewish woman (at the time of the Prophet Muhammed) who was a prostitute. As recounted in the sayings (hadith) of the Prophet, this woman offered a bowl of water to a sick dog one day though she, herself, was suffering from thirst. According to the Prophet, all her sins were forgiven based on this one act of compassion. "But," Dalel was quick to remind us:

Not everyone glorifies God through compassion in the heart, as she did, though she didn't know it. It's a function of what's in the heart of each individual. Everyone is particular. To be forgiven for a grand sin like adultery, for example, you have to regret (tawba) and commit good acts. But both regret and good acts are weak, if they are weak in your heart.

The women often discussed what it meant to have regret. The state of regret (for a sin) is said to be accepted by God only when sincere. Thus, there are specific practices, prayers,

\footnotetext{
${ }^{13}$ Killian (2007) discusses this theme as it arose in her interviews with French North African immigrant women. Her subjects were first-generation Muslim immigrants and represented a wide range of Islamic practice. They also included those who supported a ban on the headscarf. Thus, they contrasted sharply with the primarily French-born and Salafist women in my study. Killan argues that the importance attributed to "heart" reflected a comfortable compromise, in which the requirements of laïcite (that religion be private and hidden) melded with the women's beliefs that religion is foremost about faith and purity of heart. The women in my study shared this belief about faith but not out of any compromise with the state. Indeed, their belief in the burqa indicates their rejection of this interpretation of laïcité. More importantly, they believed that purity of heart comes about through external practice.
} 
and reforms in one's daily life to demonstrate regret, yet it is only when one really feels the remorse that the sin might be forgiven.

The students would frequently ask: how does one go about reforming her heart? The ambiguous answer reflected a mix of physical practice, good acts, and prayer-specifically supplications to ask God to strengthen one's faith. Indeed, there were moments when the women explored the details of physical practice in great detail, with a sense of anxiety. But there was clear acknowledgement that excessive detail about comportment can be negative. Dalel one day fielded numerous specific questions about the act of physical prostration in asking for forgiveness. Finally, she dismissed the questions: "Look, above all, in prayer you should be full of happiness. It's something primordial. My sisters, be careful about getting so caught up in details that you forget what's in fact primordial."

In addition to good acts and prayer, one's heart is strengthened through the enactment of $s a b r$ (patience) and trust in divine will in the face of life's adversities and ultimately, the fact of mortality.

To not accept the fact of death, to actually blame God, is sinful and ignorant. It's like taking the characteristics of non-believers inside of us. The act of lamentation is a contradiction of sabr. The word, sabr, derives from the word for "imprisoning." Imagine, if something tragic occurs, you can lose control and act crazy, throw yourself on the ground. Imagine instead that you draw your arms toward you, turn inward, and "imprison" or enclose that part of you, and stay calm. Sabr is like a medicine that is bitter but delivers sweetness and serenity. Especially in our Arab countries, when someone dies, you see women tearing their clothes and screaming, "woe is me!" To hit yourself, tear your clothes, is not permitted. Only God gives life, and only God can take it.

The achievement of patience and the "imprisoning" of grief is part of maintaining one's dignity, that I argue extends to all situations of suffering.

It is often through trial that one is challenged to enact patience and achieve a stronger state of heart. One woman asked Malika, "What if I think God tests me more than I deserve to be tested? I didn't sin that much after all." Malika responded, "We don't have the right to proclaim ourselves or anyone else as sinners or non-sinners. God tests the state of our hearts, and that's all. Why do we suffer maladies? The Prophet said, 'to test our hearts.' And why? 'To elevate our rewards.' Despite the agony, the recompense will be even greater." Suraiya, a French convertie, asked, "But how do you practice patience? How can I make it work?" "For example, through language," Malika responded. "Don't ever complain and lament your situation. Supplications, ask God continually to open your heart and help you develop patience."

The idea of never complaining fit a larger pattern of teachings around speech and social interaction. Specifically, through discussion of the Prophet's teachings, a number of behaviors were considered sinful, including gossip, probing personal questions, questions or comments designed to embarrass someone, lies, and spreading information of which one is unsure. "In general," said Dalel, "it's not good to talk too much. If I talk a lot, about anything and everything, I forget all remembrance of God." During my research it was not until I processed this message about speech and social behavior that I better understood the culture of this mosque community. Like most observers, I shared the tendency to view burqa-clad women as unsociable. I learned, however, that many of the women simply tried to incorporate these messages into their comportment with the goal of attaining sabr and dignity. Maintaining a degree of privacy and silence was essential to their relationship to God. While this is true to their teachings, at the same time it is difficult to entirely disentangle the phenomenon from their fear of surveillance and lack of social trust. 
With many of the mosque teachings centering on sabr in the face of adversity, even tragedy, this begged the question of whether or not it was possible to attain joy in la vie musibah (this life of suffering). Malika herself posed this question and indeed, devoted much of her sessions to addressing it, employing the writings of Sheikh Sa'di from a small booklet entitled Les Clefs pour une Vie Heureuse (Keys to a Happy Life). Many of us diligently clutched a copy of this book on a regular basis. She lectured:

It is possible to find happiness in this life of suffering (musibah). In sadness and misfortune, what is the path of [Muslim] believers? That when there is joy, you recognize it, you feel it in your heart. Only real believers recognize that these blessings come from God, that we have our eyes and ears, we can eat and drink. We can hope for other things in this life, but it is obligatory to be satisfied with everything that God gives us, even misfortunes, even grand catastrophes. My father, in Algeria, he's an old man and poor. But he's serene. You see smiles on the faces of all these poor old people in our countries [Maghreb]. Not here in France. The more riches they attain, the more they are full of worries. For all humans, it's innate to seek the way of peace. But we have the aid of God and faith. We recognize joy, and that it comes from God. This is the main difference between believers and non-believers [kafrs].

According to Malika and other teachers, it is only through love of God and patience that one might attain happiness (la vie heureuse) and embody the state of being Muslim. For this community of women this was particularly meaningful, given the multitude of obstacles in their lives, discussed earlier. Malika, herself, had a 10-year old daughter who was mentally and physically disabled. I sometimes saw her around Les Minguettes in a cheap wheelchair, and several of us would affectionately help her with schoolwork when she came to the mosque. Malika's own background thus made her lectures on serenity and faith more compelling.

She, Leila (another teacher), and Dalel addressed topics such as the importance of living in the present moment, forgetting the past, and not worrying about the future. Again, the emphasis on such themes spoke to the anxieties and fears that daunted many of the women. In the passage below the teacher reminded the women that they cannot control their life paths and must continually practice a type of discipline in order to have faith in God and thus, serenity. It also lists the women's common worries, including having children and unemployment. Finding a husband was a persistent worry, as most local Muslim men had unstable jobs or none at all.

You have to always work on yourself. If your heart has peace, then anguish and sadness disappear. You don't have work, you're worried about the future, your retirement, what'll you do when you're sixty? Or you don't have children, a husband, and worry about who'll take care of you when you're old. But we can't know the future. Only God knows - no one else can access this. An individual can't do anything to intervene other than work on herself. And we don't even know-we could die before any of these situations present themselves. So don't waste time worrying about what you may never confront.

The following two passages, each from different occasions, address the importance of letting go of past grievances and fear. Fear was often presented as a temptation of the devil, intended to lead one away from faith in God and the present moment and toward sickness.

The fourth point we discussed about the good life is to forget unpleasant things from the past. What does this mean? It doesn't mean to be amnesiac. To be human means we're constituted by our past. You can't forget but you don't want sadness to 
resurface. You have to make an effort in your heart, make an effort to close the door, struggle against the sadness when it tries to resurface.

Faith is an act of the heart-so don't let it fall into the domain of imagination. As soon as an individual falls into the domain of illusion, he's going to fall into nervous depression and sickness of the heart. Generally, the origins of our fears have no reason. How many people, in their minds, imagine problems? A mother doesn't cultivate her child's fear of darkness but tries to get him to understand that it's imaginary. You sleep alone at night, you hear a noise, and your imagination runs wild. Or the fear of losing your child is so strong that you're too anxious at the park-you worry he'll disappear when in fact, he's right there at your side. This type of fear brings anguish, sickness, in some cases hypochondria. If you trust in God, all sickness of the heart and body can disappear. There'll be a sense of peace in your chest and a joy that's indescribable. God is the creator of the sun, the moon, the earth — and so I place my faith in [him] instead of all else. This is sufficient.

This particular lecture demonstrates the utmost importance placed on one's individual relationship with God. When Malika discussed trusting God above all else, she explicitly referred to other systems of belief, other people, technologies, and the state.

Given the predominance of these themes in the women's courses at Mosquée Hasan, it was clear to me that the women were working to achieve a state of perfect faith (la foi complète), and this revolved around their ability to attain serenity and conquer their fears. Thus, their spiritual conditions - of which wearing the djelbab is an important component-were of greater importance than the reality of their material lives or political status.

\section{Conclusions}

I argued in this paper that poor Salafist women in Lyon are not engaged in a form of politics with their practice, teachings, and wearing of the burqa but rather, a form of "antipolitics." The French state has targeted the burqa, as part of a longer trajectory of stigmatizing and controlling its post-colonial subjects. It claims that the practice represents traditional authority, is an erosion of citizenship, and is oppressive to women. In other words, the state has turned wearing the burqa into a political act. The literature has an alternative view of politics but it has also politicized the burqa. While urging a rethinking of agency, freedom, and the self, in order to free Islamic Revival and women's religious activities from these statist assumptions about what constitutes citizenship, it has insisted that ethical and bodily practices are political. Accordingly, they reveal political imaginaries and forms of moral reasoning that sometimes indirectly transform the state. This is in contrast to a more conservative definition of politics that focuses strictly on direct engagement with the state.

Neither approach to politics, whether ethical practice or state-centered, aptly describes the movement of French Salafist women. The former denies any possibility of a non-political private sphere, which is the lens through which the women experience their practice, and the latter overlooks the structural weakness of poor Muslim civil societies in the banlieues and their inability to access or engage the state. I argued that antipolitics, as theorized in the 1970s and 80s to describe and shape the developing dissident movement in Eastern Europe, applies to this particular case in three major ways. Salafist women are struggling to defend and expand the private sphere against an intrusive state, building a moral community to support them 
through their ostracization, and placing greater emphasis on their spiritual state and serenity over material life. In so doing they reject all notions of politics, finding such accusations and possibilities both profane and dangerous.

The women's own rejection of politics raises crucial questions of the relationship between intention and antipolitics and under what conditions it might lead to political change. How do we approach the importance of whether or not people view themselves as political? In Mahmood's (2005) work, for example, she chose to contradict her subjects' own denial and disdain for politics by arguing that their actions were in fact deeply political. ${ }^{14}$ Although this paper has sought to question this approach, it is nonetheless important to point out the differences of context between the case of Egypt, a majority Muslim country, and France, where Muslims are a minority in a structurally weak position. Egypt's Islamic Revival was heavily intertwined with the Muslim Brotherhood, a once-powerful Islamist political group that developed out of the anti-colonial struggle. As Mahmood (2005) discusses, the activities of the Muslim Brotherhood were indeed at the forefront of the Revival. Women's mosque movements emerged from this particular trajectory (pp.62-71). Although, Mahmood herself argues, the mosque movements are not today affiliated with the Brotherhood, it is possible that adopting the burqa and certain forms of comportment had its origins in a political movement and has greater impact on the state in Egypt, where the majority population is Muslim. Thus, the women's denial of the 'profane' realm of politics might be a religious position but is not true to their historical relationship to the Egyptian state. The same, however, cannot be said of the French case, where Salafism in the banlieues did not emerge from local Islamist organizations and does not hold appeal beyond a Muslim minority.

In the antipolitical writings of Eastern Europe, there was of course a kind of doublespeak about the purpose of antipolitics - which rejected all matters of state and official power all the while leading, more clearly in some cases than in others, to the post-communist transformation. ${ }^{15}$ It is unclear whether the literature of antipolitics was indeed a political strategy, notwithstanding Havel's (1985), for example, assertion that dissidence did not come about from conscious intention (pp.57-60). How then did antipolitics become politics? It did not occur with the explicit goal of challenging the regime but rather, of autonomous parallel structures and a cultural sphere built on moral principals (Eyal 2000). Antipolitics became politics through a moral and spiritual "calling" (Eyal 2000) but combined perhaps with autonomous means of teaching and publishing. The increasing success and circulation of underground publications in time undermined the legitimacy of the regime and established the moral superiority of dissident civil society (Falk 2003; Eyal 2000). Antipolitics thus nourished the citizens' movements and roundtable talks that shaped the post-communist transition (Probst 1997).

The concept of civil society, based on "truth," was key to the antipolitics of Eastern Europe. ${ }^{16}$ More broadly, it speaks to the attractions of antipolitics in any era of political defeat or repression - where reconstructing civil society through moral community is the only hope for self-preservation and maintenance of "faith." As antipolitics was theorized,

\footnotetext{
${ }^{14}$ In her work, Eliasoph (1998) explored the complexities of this question by showing the different circumstances under which her subjects found it acceptable to "talk politics."

${ }^{15}$ It is also argued, however, that it was the failure of dissidents to directly challenge the state and develop a political agenda that undermined the development of a radically democratic civil society and gave way to neo-liberalism (Brannan 2003).

${ }^{16}$ Eyal (2000) argues that the antipolitical discourse of civil society, in which people live authentically and govern themselves with "technologies of the self," shared elements with the way civil society is used in contemporary neo-liberal doctrine.
} 
practicing autonomy from the state entails work on one's self and responsibility for one's own choices (Falk 2003; Eyal 2000). The role of faith becomes part of this moral dialogue with oneself, whether this is faith in a personal truth or a divine absolute. For Havel (1988, Letter \#78) faith was a "state of mind" and a "need to "experience the world'... in as direct and unmediated a way as possible" (p.190). For Salafist Muslims, eliminating intermediaries and public rituals is also central to their faith and hence, antipolitics. ${ }^{17}$

Some might object to this analogy, drawn between the repression of the communist regime, to which antipolitics was a response, and the interventions of the French state, which is responding to a religious practice it has deemed intrinsically antagonistic. However, the recent history of Les Minguettes is clear. With the defeat of Muslim political activists and the advent of new forms of surveillance, combined with the banning of the headscarf in public schools and an aggressive discourse against veiling, antipolitics is a response to the despair that followed the collapse of civil society. It may not be a self-conscious political strategy (despite the women's quiet opposition to regulation of religion) but rather, again, an attempt toward self-preservation. Can it become a political movement, especially if women interpret the burqa as a strictly religious obligation as opposed to a public message? Perhaps one can do no more than imagine the possibility that the ideological momentum of antipolitics could foment change in secular democracies, in this case, a shift in the very robust French political culture and its relationship to laïcité.

There are obvious differences between the history of Eastern European antipolitics and the case of Salafist women: between the moral weight of dissident intellectuals and the moral practice of poor and minority women. But despite these differences, in both cases the state is attentive to the ever-present potential that moral practice might lead to claims on either society or the state or, what amounts to the same thing, the fear that the fine line between ethical practice and politics - indeed, of the arbitrary distinction between private and public - will be breached, even in such matters as one's clothing. Given this, it is perhaps irrelevant what subjects choose and believe, when the state invariably and violently interferes in all domains of life (Foucault 1991). What is left, again, is the business of clarifying normative stakes. The women of Mosquée Hasan rejected politics, not because they were apolitical (Konrád 1984), I argue, but because their experiences in the urban periphery of Lyon led them to a movement of antipolitics. What is at stake for them in the debate over the burqa is ownership of their ethical practice and state of faith.

Acknowledgments I thank Michael Burawoy for his constant support during the fieldwork and comments, which were critical to the development of this paper. I also thank Loïc Wacquant for his encouragement and enthusiasm for the project and Cihan Tuğal for comments on an early draft. I am indebted to the many informants and friends in Lyon who gave me their support and trust. Javier Auyero and the three anonymous reviewers provided important insights and suggestions. The research was funded partially by the Center for Race and Gender, the Center for Middle Eastern Studies, and the Institute of International Studies, all at UC Berkeley. Funding was also provided by the University of California Institute on Global Conflict and Cooperation and the National Science Foundation.

Open Access This article is distributed under the terms of the Creative Commons Attribution Noncommercial License which permits any noncommercial use, distribution, and reproduction in any medium, provided the original author(s) and source are credited.

\footnotetext{
${ }^{17}$ There is a compatibility between Eyal's (2000) argument that the antipolitical emphasis on purification of one's path to truth was similar to Protestant asceticism and Olivier Roy's (2006) argument that there has been a growth of evangelical trends and purification within religions, including Islam.
} 


\section{References}

Abu-Lughod, L. (1986). Veiled sentiments: Honor and poetry in a Bedouin society. Berkeley: University of California Press. 1999.

Abu-Lughod, L. (2002). Do Muslim women really need saving? Anthropological reflections on cultural relativism and its others. American Anthropologist, 104(3), 783-790.

Ahmed, L. (1992). Women and gender in Islam. New Haven: Yale University Press.

Amiraux, V. (2008). De l'empire à la République: A propos de "l'Islam de France. Cahiers de recherche sociologique, 46, 45-60.

Arendt, H. (1958). The human condition. Chicago: University of Chicago Press.

Asad, T. (2005). Reflections on laïcité \& the public sphere. Items and Issues. Social Science Research Council, 5(3), 1-11. 2004.

Assemblée Nationale. (2009). Mission d'information sur la pratique du port du voile intégral sur le territoire national. http://www.assemblee-nationale.fr/13/cr-miburqa/08-09/index.asp.

Ayubi, N. (1991). Political Islam: Religion and politics in the Arab world. New York: Routledge.

Bacchetta, P. (2008). A transnational conversation on French colonialism, immigration, violence and sovereignty with Miriam Ticktin and Ruth Marshall. The Scholar and Feminist Online, 6(3). http://www. barnard.edu/sfonline/immigration/conversation 01.htm.

Baubérot, J. (2006). Modernité tardive, religion et mutation du public et du privé (à partir de l'example francais). Social Compass, 53(2), 155-168.

Beinin, J., \& Stork, J. (Eds.). (1997). Political Islam: Essays from Middle East Report. Berkeley: University of California Press.

Bowen, J. (2006). Why the French don't like headscarves. Princeton: Princeton University Press.

Brannan, T. (2003). From 'antipolitics' to 'anti-politics': What became of Eastern European civil society? (Working Paper No. 03-41). LSE Development Studies Institute (DESTIN).

Brown, W. (2008). Regulating aversion: Tolerance in the age of identity and empire. Princeton: Princeton University Press.

Burgat, F. (2003). Face to face with political Islam. London: I.B. Tauris.

Butler, J. (2006). Feminism should not resign in the face of such instrumentalization. IABLIS Jahrbuch für europäische Prozesse. Online. http://www.iablis.de/iablis t/2006/butler06.html. Retrieved November 2, 2009.

Césari, J. (2002). Demande de l'Islam en banlieue: Un défi à la citoyenneté. Cahiers d'études sur la Méditeraanée orientale et le monde turco-iranien, 33, 39-48.

Césari, J. (2005). Ethnicity, Islam, and les banlieues: Confusing the issues. Social Science Research Council. http://riotsfrance.ssrc.org/Cesari. Retrieved March 26, 2009.

Chouder, I., Latrèche, M., \& Tevanian, P. (2008). Les filles voiles parlent. Paris: La fabrique éditions.

Cohen, D. (1997). When quasi-citizenship is not enough: The incorporation of people of Muslim origin in two nation-states in crisis: France and Great Britain. New York: Department of Sociology, City College of New York. Ph.D. dissertation.

Connolly, W. (1983). The terms of political discourse (2nd edition). Princeton: Princeton University Press.

Connolly, W. (1995). The ethos of pluralization. Minneapolis: University of Minnesota Press.

Connolly, W. (1999). Why I am not a secularist. Minneapolis: University of Minnesota Press.

Delore, C., \& Dubois, C. (2004). Les Islamistes sont déjà là. Paris: Albin Michel.

Dikec, M. (2007). Badlands of the Republic: Space, politics, and urban policy. Oxford: Blackwell.

Dupret, B., \& Ferrié, J. (2005). Constructing the private/public distinction in Muslim majority societies: A praxological approach. In A. Salvatore \& M. LeVine (Eds.), Religion, social practice, and contested hegemonies (pp. 135-153). New York: Palgrave Macmillan.

El Guindi, F. (1999). Veil: Modesty, privacy and resistance. New York: Berg.

Eliasoph, N. (1998). Avoiding politics: How Americans produce apathy in everyday life. Cambridge: Cambridge University Press.

Esposito, J. (Ed.). (1997). Political Islam: Revolution, radicalism, or reform? Boulder: Lynne Rienner.

Euben, R., \& Zaman, M. (2009). Introduction. In R. Euben \& M. Zaman (Eds.), Princeton readings in Islamist thought: Texts and contexts from al-Banna to Bin Laden (pp. 1-41). Princeton: Princeton University Press.

Eyal, G. (2000). Anti-Politics and the spirit of capitalism: Dissidents, monetarists, and the Czech transition to capitalism. Theory and Society, 29(1), 49-92.

Falk, B. (2003). Dilemmas of dissidence in East-Central Europe: Citizen intellectuals and philosopher kings. New York: Central European University Press.

Foucault, M. (1991). Governmentality. In G. Burchell, C. Gordon, \& P. Miller (Eds.), The Foucault effect: Studies in governmentality (pp. 87-104). Chicago: University of Chicago Press. Reprinted from Aut Aut, 1978, 167-8. 
Goven, J. (1993). Gender politics in Hungary: Autonomy and antifeminism. In N. Funk \& M. Mueller (Eds.), Gender politics and post-Communism: Reflections from Eastern Europe and the former Soviet Union (pp. 224-240). New York: Routledge.

Goven, J. (2000). New parliament, old discourse? The parental-leave debate in Hungary. In S. Gal and G. Kligman (Ed.), Reproducing gender: Politics, publics, and everyday life after Socialism. (286-306). Princeton, NJ, USA: Princeton University Press.

Havel, V. (1985). The power of the powerless. In J. Keane (Ed.), The power of the powerless (pp. 23-97). Armonk: M.E. Sharpe.

Havel, V. (1988). Letters to Olga. New York: Knopf.

Hirschkind, C. (1997). What is political Islam? Middle East Report, 27(4), 12-14.

Hirschkind, C. (2006). The ethical soundscape: Cassette sermons and Islamic counterpublics. New York: Columbia University Press.

Hourani, A. (1983). Arabic thought in the liberal age. Cambridge: Cambridge University Press. 1962.

Kaltenbach, J., \& Tribalat, M. (2002). La République et l'Islam: Entre crainte et aveuglement. Paris: Gallimard.

Karam, A. (Ed.). (2004). Transnational political Islam: Religion, ideology and power. London: Pluto.

Khan, S. (1998). Muslim women: Negotiations in the third space. Signs, 23(2), 463-494.

Killian, C. (2007). From a community of believers to an Islam of the heart: "Conspicuous" symbols, Muslim practices, and the privatization of religion in France. Sociology of Religion, 68(3), 305-320.

Joppke, C. (2009). Veil: Mirror of identity. Cambridge: Polity Press.

Konrád, G. (1984). Antipolitics. New York: Harcourt Brace Jovanovich.

Laurence, J., \& Vaisse, J. (2006). Integrating Islam: Political and religious challenges in contemporary France. Washington, D.C.: Brookings Institution Press.

LeVine, M., \& Salvatore, A. (2005a). Introduction: Reconstructing the public sphere in Muslim majority societies. In A. Salvatore \& M. LeVine (Eds.), Religion, social practice, and contested hegemonies (pp. 1-25). New York: Palgrave Macmillan.

LeVine, M., \& Salvatore, A. (2005b). Socio-religious movements and the transformation of "common sense" into a politics of "common good. In A. Salvatore \& M. LeVine (Eds.), Religion, social practice, and contested hegemonies (pp. 29-56). New York: Palgrave Macmillan.

Levy, J. (1999). Tocqueville's revenge: State, society, and economy in contemporary France. Cambridge: Harvard University Press.

Macleod, A. (1991). Accommodating protest: Working women, the new veiling, and change in Cairo. New York: Columbia University Press.

Mahmood, S. (2003). Ethical formation and politics of individual autonomy in contemporary Egypt. Social Research, 70(3), 837-866.

Mahmood, S. (2005). Politics of piety: The Islamic revival and the feminist subject. Princeton: Princeton University Press.

Mernissi, F. (1985). Beyond the veil: Male female dynamics in modern Muslim society. Bloomington: Indiana University Press.

Nasr, S. (2001). Islamic leviathan: Islam and the making of state power. Oxford: Oxford University Press.

Probst, L. (1997). What's left? Antipolitics and the decline of the East German citizens' movement in postunification Germany. New German Critique, 72, 137-149.

Putnam, R. (2000). Bowling alone: The collapse and revival of American community. New York: Simon and Schuster.

Renwick, A. (2006). Antipolitical or just anticommunist? Varieties of Dissidence in East-Central Europe, and their implications for the development of political society. East European Politics and Societies, 20(2), 286-318.

Riesebrodt, M. (1993). Pious passion: The emergence of modern fundamentalism in the United States and Iran. Berkeley: University of California Press. 1990.

Roy, O. (1994). The failure of political Islam. (C. Volk, Trans.). Cambridge: Harvard University Press.

Roy, O. (2004). Globalized Islam: The search for a new ummah. New York: Columbia University Press.

Roy, O. (2006). Islam in Europe: Clash of religions or convergence of religiosities? In K. Michalski (Ed.), Conditions of European solidarity, vol II: Religion in the new Europe (pp. 131-144). New York: Central European Press.

Salvatore, A. (2007). Authority in question: Secularity, republicanism, and 'communautarisme' in the emerging Euro-Islamic public sphere. Theory, Culture \& Society, 24(2), 135-160.

Scott, J. (2007). The politics of the veil. Princeton: Princeton University Press.

Scott, J., \& Keates, D. (Eds.). (2004). Going public: Feminism and the shifting boundaries of the private sphere. Urbana and Champaign: University of Illinois Press.

Stemmann, J. (2006). Middle East Salafism's influence and radicalization of Muslim communities in Europe. Middle East Review of International Affairs, 10(3), 1-14. 
Strieff, D. (2005). Forging a voice in "France's high-rise hell." MSNBC. http://www.msnbc.msn.com/id/ 12812186/page/2/. Retrieved July 7, 2006.

Tissot, S. (2006). Y a-t-il un "Problème des Quartiers Sensibles"? Retour sur une catégorie d'action publique. French Politics, Culture \& Society, 24(3), 42-57.

Tissot, S. (2008). "French suburbs": A new problem or a new approach to social exclusion? (Working Paper Series \#160). Center for European Studies.

Tuğal, C. (2009). Transforming everyday life: Islamism and social movement theory. Theory and Society, 38 , 423-458.

Wacquant, L. (2008). Urban outcasts: A comparative sociology of advanced marginality. Cambridge: Polity Press. Warren, M. (1999). What is political? Journal of Theoretical Politics, 11(2), 207-231.

Wenman, M. (2003). What is politics? The approach of radical pluralism. Politics, 23(1), 57-65.

Wilson, P. (Ed.). (1992). Open letters: Selected writings 1965-1990. New York: Vintage.

Z. Fareen Parvez is an Assistant Professor of Sociology at the University of Massachusetts, Amherst. This article draws from her dissertation, a comparative ethnographic study of Islamic movements in Lyon, France, and Hyderabad, India. 